\title{
Qualifications of Subject Teachers in Special Education Schools
}

\author{
Meryem Uçar Rasmussen ${ }^{1}$, Arzu Kış ${ }^{2}$ \\ ${ }^{1}$ Abant İzzet Baysal University, Turkey \\ ${ }^{2}$ İnönü University, Malatya, Turkey \\ Correspondence: Meryem Uçar Rasmussen, Abant İzzet Baysal University, Turkey.
}

Received: December 25, 2016

Accepted: February 25, $2018 \quad$ Online Published: March 6, 2018

doi:10.11114/jets.v6i4.2093

URL: https://doi.org/10.11114/jets.v6i4.2093

\begin{abstract}
Teacher qualifications are essential to be able to teach children with special needs efficiently. Therefore the aim of this study is to determine the qualifications of subject teachers in special education schools in Turkey. In the study 20 subject teachers within the field of music, art and sports who worked in special education schools in Turkey participated. Qualitative research methods were used and the research data was collected using a semi-structured interview technique in the form of a questionnaire, collecting information about the teachers' knowledge on the field of special education, what problems they encounter and what needs they might have. The data was analyzed using content analysis. The results show that the subject teachers in this study do not possess adequate knowledge about the students' different disabilities and their characteristics. Beside the lack of knowledge the teachers also express a lack of tools, materials, and workshop rooms for art and music, a school gym, extra time, training, support services, in service programs, and collaboration with colleagues. Furthermore the teachers express insufficient qualifications in making lesson plans, teaching, assessing, managing the classroom, changing student behavior, and parent training. The teachers in the study expressed that the lack of training support and services, the lack of peer support and negative attitudes from colleagues and school administrators to subject teachers reduced their motivation and prevented them from teaching efficiently. All in all the lack in requirements can be divided into three respective ranking areas 1) teacher knowledge, 2) classroom materials, tools and equipment and 3) training, management and peer support. Even though the subject teachers express a seeking for support, the inadequate fulfillment of the requirements within the areas as mentioned above affect the teaching negatively and prevent the subject teachers from teaching children with special needs efficiently.
\end{abstract}

Keywords: special education, subject teachers, teacher qualifications

\section{Introduction}

Teacher training applications in the field of special education is a new process for Turkey (Akçamete, 1998; Özyürek, 2008). In Turkey, the first teacher training in special education began in the 1952-1953 academic year as a special education subject and was established at Gazi Institute of Education. It was performed by including teachers who had at least 3 years primary school experience to the special education program for two years. However, the program was closed after two years. Until 1983 other subject teachers who worked in the public education schools were placed in the field of special education to eliminte the lack of teachers there. (Akçamete, 1998). In Turkey the application training of special education teachers as class teachers began with the Special Education Department which was founded at Anadolu University in 1983. The number of universities which trained special education teachers was implemented at Ankara University, Gazi University (1987) and Abant İzzet Baysal University (1994).

Today there are 31 universities which faculties of education have departments of special education. Until 2016 under the name of the department of special education, teachers were trained in 4 major fields of study, including; the mentally challenged, visual disability teacher, hearing impairment teacher and gifted teacher. On June $4^{\text {th }} 2016$ the Council of Higher Education made the decision to merge the 4 major department fields under one roof, calling it the special education teacher degree program from the academic year 2016-2017.

In the curriculum of special education departments 3 credits are given for one semester classes such as teaching art and craft to students with mental disabilities, teaching music to students with mental disabilities, and teaching physical education and games. In the curriculum of education faculties where the teachers include subject teachers such as art teachers, music teachers and physical education teachers, a class associated with special education and inclusion is offered. 
The teachers, students and the curriculum are the cornerstones of the educational system. These 3 cornerstones have to work in harmony with each other, because efficient and effective education can only be achieved if they are in harmony. The teacher is the most important element to ensure this harmony. There is a positive and strong link between the success of the education system, the quality of the students who are products of the education system and the quality of the teacher who is the main determinant for efficiency (MEB, 2013; Sezgin, 2006). In the studies which have examined student achievement and qualification/teaching skills of teachers, it was demonstrated that there is a correlation between student achievement and qualification/professional experience of teachers (Özer and Gelen, 2008). Haycock (1998) as a result of his study stated that there is a clear association between low student achievement, low level curriculum, and untrained teachers.

Teacher qualifications and successful teacher performance depends on quality training in pre-service education (Erişen and Çelikgöz, 2003; MEB 2008). The primary task of institutions where teachers are trained is to educate "qualified teachers". A qualified teacher must possess the knowledge of her/his area of occupation (Zengin and Akgün, 2010; Turkish Educational Association, 2009; Kayabaş1, 2008; Özyürek, 2008; Şeker, Deniz and Görgen, 2005), have skills for planning and implementing teaching with proper methods and techniques according to the students characteristics. A qualified teacher must also possess skills for monitoring and assessing the effectiveness of the teaching and development of the students. Teachers must also know how to manage the classroom and student behavior, use technology, collaborate with other teachers, school management and family (Turkish Educational Association, 2009; Şeker, Deniz and Görgen, 2005), and finally the personality and values of the teacher must be in harmony with the requirements of the profession (Zengin and Akgün, 2010; Kayabaş1, 2008; Şeker, Deniz and Görgen, 2005).

At the end of the study the general qualifications of teachers was determined and published in collaboration with the Ministry of Education and Council of Higher Education. General qualification of teachers was determined in 6 main qualification fields including personal and professional values, professional development, recognition of students, the process of teaching and learning, monitoring and assessing of learning and development, relations with the school, parents and the community, programs and content knowledge. Furthermore 39 sub qualification fields and 244 performance indicators related to the 6 main qualification fields was determined. The general qualifications of teachers were reevaluated by a commission formed by teachers from June $21^{\text {st }}$ to June $25^{\text {th }} 2004$. The evaluation resulted in the invariably adaptation of the 6 main qualification fields, although the sub qualification fields were reduced from 39 to 31 and the performance indicators from 244 to 221 (MEB, 2006). Additionally, it was stated that variables in teacher's qualifications such as patience, intelligence, knowledge of the field, positive attitude, verbal ability, sincerity, ambition, open mindedness and collaboration ability are the important qualities which come before others (Jain, 2013).

Arts education is part of the curriculum for students with special needs as well as other discipline areas (Çağlayan, 2014). Activities of the art classes which emerge as an expression of understanding the ability and creating power of children, attract attention as an indicator of mental development. Art education like drawing, coloring and painting include processes that will help children, whether with special needs or not, show their inner world, socialize in conducted group work and develop fine motor skills (Erim and Caferoğlu, 2012).

In music classes individuals have intensive interaction with each other, which allows them to express themselves both individually and in groups (Güven and Çevik, 2012). Music classes have an aesthetic value as well as being a very important teaching tool for educators. Music classes allow individuals to feel a sense of achievement. These classes are very valuable especially in the education of students with special needs. Therefore, it should be placed into the program for students with special needs as well as for students in mainstream education (Artan, 2001).

Physical education helps children with special needs to control their emotions like aggression, anger and jealousy which emerge as both a natural result of the mood they are in and the public attitude towards them because of their disabilities (Illhan, 2008).

The effectiveness and benefits of subject classes such as art, music and physical education on students with or without special needs have been studied by Erim and Caferoğlu, (2012); Salderay, (2008); İlhan, (2008). In their studies, it was stated that art, music and physical education classes help students with special needs to support development of gross and fine motor skills, hand-eye coordination, academic skills, emotional structure, and adaptation level to social life (Erim and Caferoğlu, 2012; Salderay, 2008), sharing, group adaptation and language skills (Erim and Caferoğlu, 2012; İlhan, 2008). Furthermore, these subject classes also help them develop their individual identity, experience success and a sense of achievement, increase their confidence and courage, develop power of expression, increase the structure of perception, develop creativity, and increase independence (Salderay, 2008). In the study, it was seen that teachers believe in the need of special education and they want to help students with special needs in or outside of the classroom, but have a lack of knowledge and skills in special education and feel insufficient, (Gökay and Özalp, 2000).

Considering the knowledge and skills which the subject teachers who work in the special education field need to have, 
it is thought to be important to examine the terms of the working conditions in the field, the success, satisfaction and qualification of subject teachers. Determining the status of teachers, assessment of performance according to the obtained results and determining appropriate arrangements is important.

All in all teacher qualifications are essential to be able to teach children with special needs efficiently. Therefore the aim of this study is to determine the qualifications of subject teachers in special education schools in Turkey.

\section{Method}

Model Research: The study was designed as a descriptive study with qualitative research methods and the data collected using a semi-structured interview technique.

Participants: In the study 20 subject teachers within the field of music, art and physical education who worked in special education schools in Istanbul, Turkey between 2013 and 2014 participated. 14 of the participants were women, 6 of the participants were men. They were between 25-42 years old.

Data collection tools: In the study a form consisting of 32 semi-structured questions and a demographic questionnaire including personal information was used to collect data. To create this questionnaire, first the literature was reviewed, then a question pool was composed viewing question content of similar kind and draft questions were prepared. The final shape to interview questions was given eliminating similar questions by an expert who serve as an academician in the field of special education. The questions were sent to the teachers who work in special education schools by electronic mail and they were asked to fill them out and send them back.

Data Analysis: Analysis of the data obtained was conducted using content analysis method. Content analysis is the process of in-depth analysis of collected data and by bringing together similarities under certain themes. Content analysis made it possible to reveal previously non-obvious themes and dimensions (Yıldırım and Şimşek, 2008). For analysis, firstly, the given answers to the questions in the questionnaire were grouped together, consisting of 39 pages of data. The data was analyzed in two copies by independently researchers and common themes were determined. The similar answers were combined in a framework of specific concepts and themes and then interpreted. The findings were presented under the themes and sub-themes referring to the participants' answers as loyal as possible to the original data.

\section{Findings}

In this section the findings are presented under three main categories 1) Education background, 2) The reason for choosing the field of special education and 3) The problems experienced.

\subsection{Education Background}

Education background, including pre-service education and in-service training.

Pre-service education: In the study, it was found that only $40 \%$ of the teachers had attended classes about special education (only one semester), but they stated that these classes were not sufficient to work in the field. The rest of teachers had not received any classes about special education.

In-service training: In the study of the teachers, $65 \%$ expressed that they had not been subjected to any in-service training after they had begun work and only $15 \%$ of the teachers had received in-service training. $20 \%$ of the teachers did not give any answer. In addition, $65 \%$ of teachers expressed that if in-service training is planned well, it will be effective to increase teacher qualification in special education. "If you plan really productive training, of course training will be very effective. But in general we go and attend this kind of training just for the signature and mostly it seems a burden to us. ... "(Analysis form page 35/teacher no. 8), "If service training course is well planned and implemented it would be effective for teachers." (Analysis form page 35/teacher no. 16), "Of course in-service training would be effective if the course activities carried out take the attention of the teachers, the teachers would not just sign and escape from the course place and it would be effective." (Analysis form page 35/teacher no. 17). 20\% of teachers expressed that in-service training are not effective "Absolutely not... We regularly went to the in-service training but during 3 hours we just chatted and we did not receive any training." (Analysis form page 35/teacher no. 15.), 15\% stated that they do not know if in-service training is effective or not, because they did not take in-service training.

\subsection{The reason for Choosing Special Education Field}

According to the findings, it has been determined that $40 \%$ of subject teachers work in special education school willingly, $60 \%$ of them work because of obligatory reasons such as a higher chance of occupation in the field of special education compared to mainstream education, and to be close to their home or their spouses work place. Of the teachers stating obligatory reasons, $25 \%$ of them said that they chose to work in the field of special education because of a higher chance of being appointed to a state school and an easier appointment in general "...special education schools are not preferred by subject teachers, so chances of appointment are higher" (Analysis form, page 3/teacher no. 6), "To be 
appointed (to a state school)" (Analysis form page 3/teacher no. 8) "I chose it to be appointed to the city I wanted." (Analysis form, page 3/teacher no. 17), "No. I had to choose. Because the service points of the city where I wanted to work was so high, I thought I could save enough service points to be appointed to that school." (Analysis form, page 3/teacher no. 11). $35 \%$ of the teachers stating obligatory reasons, said that they preferred to work in the field of special education because of their spouse "...I chose it because of peer status." (Analysis form, page 3/teacher no. 10), "No. I was forced to choose it because of my spouse." (Analysis form, page 2/teacher no. 2),

or the special education school was close to their home or their spouses "I chose it because it was close to my home"(Analysis form, page 3/teacher no. 12), "I chose it to be close to my spouse's work place" (Analysis form, page 3/teacher no. 15).

\subsection{The Problem Experienced}

Subject teachers stated that they had some problems when they work in the field of special education. These problems are categorized as 1 . Problems related to knowledge of special education, 2. Problems related to cooperation and attitudes and 3. Problems related to physical and teaching conditions and support services.

\subsubsection{The Problems Related to Knowledge of Special education}

The term "knowledge about the field" includes knowing the characteristics of students with special needs, individualized educational programs (IEP), teaching, assessing, managing class and behavior and parent training.

To know students characteristics: 55\% of the subject teachers expressed that they know the characteristics of children with special needs. Most of these teachers did not receive pre-service training about special education and did not join any in-service training. 30\% of the subject teachers expressed that they knew very little about the characteristics of children and that it was not sufficient. Most of these teachers received pre-service education about special education but did not join any in-service training. 15\% of the subject teachers expressed that they did not know anything about the characteristics of children. None of these teachers received pre-service training about special education and did not join any in-service training. "....sometimes, I realize that I lack knowledge especially related to the type of disability..." (Analysis form page 23/teacher no. 10), "I do not feel sufficient in this field. We came to this kind of school with almost no knowledge about the field. We learned things about the field through experience." (Analysis form page 2/teacher no. 7). $30 \%$ of the subject teachers reported that they feel sufficient in special education. Half of these teachers took special education classes during their pre-service training, but most of them did not join any conferences or seminars. $70 \%$ of the subject teachers expressed that they don't feel sufficient in the field of special education. Most of these teachers took a class about special education at university but did not join any in-service training. "I do not feel sufficient in the field of special education, because I do not know how I should behave with them." (Analysis form, page 24/teacher no. 12), "The biggest challenge working with children with special needs is to be patient and to know what you have to do." (Analysis form, page 28/teacher no. 11).

Individualized educational programs (IEP): $35 \%$ of the subject teachers stated that they feel sufficient about planning, $55 \%$ of them do not feel sufficient, "....even I don't know how we can make a plan and according to what we need to plan like $\boldsymbol{I E P}$, which we have to prepare before teaching... We just take a ready plan and make some changes to it and use it." (Analysis form, page 24/teacher no. 11) and 10\% of them feel very little sufficient. One part of the subject teachers who thought themselves sufficient, expressed that they considered student characteristics while planning. Another part of the teachers expressed that they determine goals according to the class, and they used ready plans and made small changes to it. "I use IEP which is simple" (Analysis form page 21/teacher no. 4), "We make some small changes to an IEP given by other teachers and use it (Analysis form page 23/teacher no. 8)," and they stated that they actually do not know how to make individualized educational program ".....we make IEP only because we need to. Most of us do not know what an IEP is, why and how we are supposed to do it"

Teaching: $25 \%$ of subject teachers expressed that they know teaching methods and techniques used in special education (some of them took a special education class during their pre-service education and received in-service training), "Yes. I am very good at communicating with children. They love me and I love them, so I can carry out my class with less problems." (Analysis form, page 25/teacher no. 16), 40\% of them expressed that they do not know teaching methods and techniques used in special education "I do not know the exact names of the teaching methods ..." (Analysis form, page $7 /$ teacher no. 3) and 35\% of them expressed that they know very little about it. "I know very little about teaching and assessment methods and techniques. I don't work with them (students) systematically, but I am doing my best to make them feel relaxed and have fun as much as possible." (Analysis form, page 23/teacher no. 10), "I know several teaching methods which I learned from special education class teachers. I do not know how correct they are" (Analysis form, page 9/teacher no. 9). $40 \%$ of subject teachers expressed that they find themselves sufficient in terms of teaching in special education, $50 \%$ of them expressed that they do not feel sufficient, and $10 \%$ of them expressed that they feel very little sufficient. "Deficiencies in the planning are affecting teaching negatively." (Analysis form on page23/teacher no. 8). 
Assessment: $10 \%$ of subject teachers expressed that they know assessment methods and techniques in special education, "We are making plans according to their (students) performance related to time." (Analysis form, page 10/teacher no. 19), "the important thing is to perform goals independently." (Analysis form, page 25/teacher no. 20), 70\% of them expressed that they do not feel sufficient, "I assess students according to my criteria. I do not use any scale." (Analysis form, page 23/teacher no. 8), "Obviously I do not think it is necessary to assess students with special needs. I just assess them according to their efforts in the classroom. I am happy to see their development. So I do not use any method to assess them" (Analysis form, page 8/teacher no. 7) and $20 \%$ of them expressed that they know very little about assessment methods and techniques. "Actually I know just little about assessment. I assess the students with their class teacher at the end of the semester" (Analysis form on page 9/teacher no. 10), "I do not know the exact names of the assessment methods. Mostly I give them points based on my observation and feelings because I know that assessment is flexible in special education." (Analysis form on page 7/teacher no. 3), "In terms of assessment, I'm trying not to separate them from normal children. I'm just minimizing my criteria. I do not know if I am supposed to do this. But I think it's appropriate." (Analysis form on page 22/teacher no. 6). $25 \%$ of subject teachers expressed that they feel sufficient in terms of assessing children with special needs, "I find myself sufficient. I think at least I am doing my best." (Analysis form, page 21/teacher no. 3), $70 \%$ of them expressed that they do not feel sufficient, and 5\% of them expressed that they feel very little sufficient.

Managing class and behavior: $45 \%$ of subject teachers expressed that they find themselves sufficient in terms of managing classroom and behavior, "I feel sufficient because I improve myself by attending seminars." (Analysis form, page 21/teacher no. 5), $40 \%$ of them expressed that they do not feel sufficient, “...It takes longer time to think how I should behave to students with behavior problems." (Analysis form, page 26/teacher no. 11), "...I do not know what to do to students with serious behavior problems. Generally, the class teachers sit with students and try to make them watch what we do" (Analysis form, page 24/teacher no. 13), and 15\% of them expressed that they feel very little sufficient. "I am having difficulties in the class which have students with behavior problems." (Analysis form, page 21/teacher no. 5) "I love students very much, but sometimes I am inadequate with their needs. I am having problems understanding students with speech difficulties beside mental disability and deciding what I need to do to deal with behavior problems." (Analysis form page 27/teacher no. 17). "It can be difficult to cope with students who have behavior problems. I don't know what to do when I am faced with aggressive behavior." (Analysis form, page 27/teacher no. 15).

Se According to these findings, half of subject teachers have some difficulties such as managing the classroom and behavior, knowledge about behavior management methods and techniques or insufficient knowledge. They do not know what to do when they are alone with students who have behavior problems.

Parent training: $15 \%$ of subject teachers expressed that they find themselves sufficient in terms of parent training, $70 \%$ of them expressed that they do not feel sufficient, and $15 \%$ of them expressed that they do not communicate with parents. "I do not do any work related to the family. We do not meet too often, but we come face to face with what needs to be done about the administration." (Analysis form page 24/teacher no. 11), "I have not had much contact with the family." (Analysis form page 21, 6 teacher), "We don't have to meet too often with parents, because class teachers communicate with them. I didn't take any training about how to communicate with them." (Analysis form page 21/teacher no. 3).

\subsubsection{The Problems Related to Cooperation and Attitudes}

$35 \%$ of subject teachers stated that they received help from other teachers who have knowledge about special education and this help was sufficient. "They try to help us as much as they can possibly do. I am thinking it is sufficient for me." (Analysis form page 32/teacher no. 3), 35\% of them stated that they received help but it was not sufficient for them. "I have received some help from other teachers but it's not like training at university." (Analysis form page 32/teacher no. 9), "I have received some help but it is only enough for solving the current problems." (Analysis form page 32/teacher no. 18), $30 \%$ of them stated that they did not receive any help. "I do not receive it. Some special education class teachers try to help us but others approach us with attitudes like go and find it out yourself. I cannot deal with you now." (Analysis form page 31/teacher no. 6), "I need help from special education class teachers." (Analysis form page 30/teacher no. 3), "Unfortunately most of teachers leave us alone by preferring to rest, instead of helping us who are not experts in our classes." (Analysis form page 19/teacher no. 18), "....most of the special education teachers see our subject classes as break time" (Analysis form page 17/teacher no. 7).

In the study, $40 \%$ of subject teachers stated that other teachers have positive attitudes about subject classes and believe subject classes are as important as academic classes, "The other teachers show respect to me and my class." (Analysis form, page 15/teacher no. 1), 60\% of them stated that other teachers have negative attitudes about subject classes and think subject classes are less important compared to academic classes, and this decrease their motivation. "This issue makes me feel sad and decrease my motivation." (Analysis form page 16/teacher no. 6).

$35 \%$ of subject teachers stated that school management have positive attitudes about subject classes and believe the 
subject classes are as important as academic classes. Also they stated that school management provide all materials that subject teachers need. They stated that all this increased subject teacher's motivation. $65 \%$ of them stated that school management have negative attitudes about subject classes and think subject classes are less important compared to academic classes, and this decrease their motivation "Managers do not give particular attention to the subject classes." (Analysis form page 19/teacher no. 16), "School management doesn't care much about subject classes. They see it as at drudgery. The school management only care that we complete classes seamlessly. How effective we teach is not the most important thing for them. Most of the time the school manager rather than supporting us, puts more obstacles in front of us by assigning us administrative work." (Analysis form page 33/teacher no. 6), and they stated that school management did not provide or provide very little of what they need, such as materials, tools, workshops and getting information, "Our requests were always postponed despite them being very affordable."(Analysis form page 33/teacher no. 7), "The biggest challenge is to work with managers who don't understand the importance of this class. They made us more tired than students ..." (Analysis form page 29/teacher no. 16).

\subsubsection{The Problems Related to Physical and Teaching Conditions and Support Services}

Physical and teaching conditions: 95\% of subject teachers stated that they need workshops and materials "......equipped workshops, internet, and computers and so on." (Analysis form page 30/teacher no. 7), "The lack of separate workshops, the need to work in the classroom, the lack of an art workshop impact my teaching negatively." (Analysis form page 30/teacher no. 8), "More variety of educational materials and physical education environments. (Analysis form page $30 /$ teacher no. 16), and $5 \%$ of them stated that they need extra time for preparation and break time.

Support services: While $25 \%$ of subject teachers expressed that they have some information about support services and are provided some support services, "If what is called support services mean to provide material and help, then my school is providing me support services." (Analysis form on page 11/teacher no. 3), 75\% of them expressed that they do not have any information about support services and are not provided any support services. "I did not come across any (support services) at all actually." (Analysis form on page 12/teacher no. 7), "If they had been provided I guess I would have been informed about it." (Analysis form on page 12/teacher no. 12), "I don't know, if support services are provided." (Analysis form on page 12/teacher no. 17).

\section{Discussion and Results}

As well as special education teacher candidates, other teacher candidates must also be trained in special education. The necessity of this emerges in the modern education system. According to the findings of the research, it has come to light that subject teachers start to work in the field of special education without having gained sufficient knowledge about special education during their pre-service training. In the literature, it has been determined that the teachers who could not receive adequate or efficient education about their working area during their pre-service training, feel insufficient, have negative attitudes and are at a higher risk of burnout (Güven, 2011; Babaoğlan and Yılmaz, 2010; Kılıç, 2009; Alpay, 2009; Sabanc1 and Şahin, 2006; Sarı and Bozgeyikli, 2003; Oral. 2000). On the other hand, the teachers who receive training in their working area have more positive attitudes and opinions about their work (Güven and Çevik, 2012; Yıkmış and Gözün, 2004; Orel, Zerey and Töret, 2004).

Turkish Education Association (2009), emphasizes that development of quality education is dependent on the development of teachers' professional qualification in Turkey, and that pre-service education and in-service training, which provide continuous professional development, has highest priority in terms of the quality and development of teachers' qualifications. Additionally, it is indicated that effective in-service training increases the perception of sufficiency of teachers (Karacaoğlu, 2008). In the study, it has been obtained that the majority of the subject teachers did not receive in-service training or the training was not effective. Well planned in-service training programs would be effective. In the literature, it can be seen that a large majority of teachers who work in special education schools believe that in-service training is necessary (Başaran, 2001), but in-service training did not reach its purpose and was not sufficiently effective (Sabancı and Şahin, 2006; Turkish Education Association, 2009; Kazu and Kerimgil, 2008; Sanioğlu, Büyükkaragöz, Duman and Sarı, 2008; Özaydın, Çolak, 2011) and in-service training programs are inadequate in terms of source, methods, strategies and practices (Turkish Education Association, 2009).

In the study it was found that a large majority of subject teachers' did not choose to work in the field voluntarily and had chosen it for obligatory reasons. It has been thought that the reason why subject teachers do not choose the field of special education voluntarily, is because of their lack of knowledge of the field. It is thought that the insufficient training cause subject teachers to look at the field of special education with fear and reluctance. In addition, not working voluntarily adversely affected their motivation and the efficiency of the teaching negatively. In the literature some studies stated that the teachers who did not choose their field or profession willingly, perceived working conditions inadequately (Başaran, 2001), and could not reach satisfaction because they experienced emotional burnout (Cemaloğlu and Şahin 2007; Oruç, 2007). Additionally, Turkish Education Association (2009) stated that one third of teachers are 
not interested in the teaching profession and do their job involuntary. They choose their job for obligatory reasons.

Individualized Educational Program (IEP) is an important program that can provide information about individuals with special needs. This program is the best resource to begin to learn about students and determine their short and long term academic and social goals (Bryant, P., Smith and Bryant, R., 2008). According to the findings, subject teachers who work in the special education field are not sufficient in parent training, making individual educational programs (IEP), teaching, assessing, and managing class and behavior using the methods and techniques related to the students. Also they expressed they do not feel sufficient in the field.

In the study of Nizamoğlu (2006) it was found that class teachers do not do systematic study in terms of determining the aims, and that they determine unwritten aims according to their own methods. They do not do any planning applying methods and activities in order to facilitate student interaction. They have problems and are not sufficient in appropriate teaching for students with special needs and in the study of Çetin and Çetin (2000) it was found that the subject teachers who work as a class teacher had problems in teaching the students. In the literature there are other similar studies indicating that class teachers are not sufficient to assess students with special needs, they are inadequate in using alternative assessment methods and tools and usually use traditional assessment methods (Nizamoğlu, 2006; Battal, 2007, The Turkish Education Association, 2009). Classroom management is an important skill that affects education (Emmer, Stough, 2001; Berlin, 1988), but many teachers have difficulty in maintaining class domination and discipline (Turkish Education Association, 2009).

Improved teacher preparation is a necessity. Student outcome strongly depend on the effectiveness of the teaching, but regrettably many teachers report that they feel unprepared to work effectively with students with special needs (Smith, 2011). In addition, there are some studies which found that the most of teachers who work in a different field than their own, do not have sufficient field knowledge and this affect their teaching adversely (Turkish Educational Association, 2009; Nizamoğlu, 2006; Scout, 2005; Kumar, 2003; Oral, 2000). They do not have sufficient knowledge about special education and are not offered sufficient support services for students with special needs (Altun and Gülben 2009), the teachers who have knowledge of the field feel more sufficient than the teachers who do not have knowledge of the field (Gökyer and Ozer, 2014, Babaoğlu and Yilmaz, 2010). The teachers who do not have sufficient knowledge about inclusion have some problems in their classes (Gök and Erbaş, 2011), and this lack of knowledge in their working field caused them to quit their job in special education and return to their own field (Çepni, Cerrah and Bacanak 2002).

The capabilities of teachers to work together in an environment where they are appreciated, affects the quality of education and provide to create a positive school environment. The teachers who are not appreciated by their superiors, experienced more burnout, and it affected their success and willingness negatively (Oruç, 2007; Cemaloğlu and Şahin, 2007; Çetin and Çetin, 2000). According to the findings, a majority of other teachers and school managements have negative attitudes towards the subject classes. They reduced the priority of the classes, they don't collaborate enough, and they do not share their knowledge and do not provide what subject teachers need. Additionally, school management gives other duties to subject teachers and prevent them from joining their own class. This case leads to a decrease in subject teachers' motivation and affect education negatively. In similar studies, it is stated that the level of collaboration between teachers affect students' performance (Gully and others, 2002). For teachers who work in a different area than their own, a lack of solidarity and cooperation among teachers strengthened their wish to return to their own field (Çepni, Cerrah and Bacanak, 2002). In inclusion classes, even though class teachers receive help, this help is not sufficient or functional (Saraç and Çolak, 2012).

Special education class teachers are not sufficient in art class and art therapy for students with special needs (Gökay and Özalp, 2000; Erim and Caferoğlu, 2012). Special education teachers and subject class teachers do not have sufficient knowledge about each other's field thus, it can cause mayhem in the special education process. It can be considered the reason of why other teachers were not sufficient to help and guide subject class teachers in the special education field, because their knowledge in their subject classes was not adequate.

It has emerged that subject teachers experienced some difficulties about physical and teaching conditions such as lack of equipped workshops and appropriate tools for teaching. They are limited in teaching and because of physical and teaching conditions, it prevents them from teaching effectively. Studies in the literature support that physical conditions and class equipment was not sufficient for teaching (Başaran, 2001; Özaydın and Çolak, 2012), the students would express themselves better if teaching was performed in workshops prepared according to students disability and with a variety of materials, teaching techniques and methods (Erim and Caferoğlu, 2012).

According to the findings most of subject teachers did not receive any support services. Even most of them did not know what support services are. In the report, Education Status Through Inclusion/Integration in Turkey (2011) and in Nizamoğlu (2006) it was emphasized that there is a lack of educational support services in Turkey and teachers only receive assistance from counseling teachers as a support service in their schools and they do not interact adequately 
with experts out of school. The teachers do not receive sufficient support services thus this situation affects quality of education negatively.

As a result it emerged that the pre-service training of subject teachers was not sufficient to work in special education. Adequate efficient in-service training was not provided when they start to work in the field thus subject teachers face problems like lack of knowledge, cooperation with colleagues, negative attitudes and inadequate physical and teaching conditions. So all these reasons lead to subject teachers feeling insufficient in special education and impact their teaching negatively.

Therefore, in order to eliminate the negative effects of the lack of knowledge and have qualified teachers, firstly it is recommended that the universities increase the quality of pre-service training by collaborating with special education schools, increasing the number of special education classes and the credit of classes. The content of the classes must be developed according to the lack of knowledge and experienced problems among the teachers. Additionally, this will increase the possibility that subject teacher choose special education schools willingly.

It is furthermore necessary to determine what workshops, equipment, instruments, and materials are needed to gain the full potential of the students' ability and provide these.

The other case is the lack of support services. To solve this problem, teachers must be informed about support services, and be given support services from experts who work with the relevant disabilities.

Another important issue is collaboration and negative attitudes. To increase collaboration between teacher-teacher and teacher-parent, meetings must be scheduled and enforced by the school management as part of the weekly work routine.

The negative attitude from colleagues and reduced priority of subject classes from the management can be changed with in-service training and teacher collaboration about subject classes to realize their unexplored potential and importance for teaching communicative and social skills. It will increase motivation and enable teachers to do their job willingly and gladly.

Applying some or all of these solutions will result in better qualified subject teachers in the field of special education and as a result an increase in the benefits of subject classes.

\section{References}

Alpay, A. (2009). Öğretmenlerin hizmet öncesi öğretmenlik eğitimlerini değerlendirme. Kuram ve Uygulamada Eğitim Bilimleri, 9(3), 1085-1123.

Altun, T., \& Gülben, A. (2009). Okul öncesinde özel gereksinim duyan çocukların eğitimindeki uygulamalar ve karşılaşılan sorunların öğretmen görüşleri açısından değerlendirilmesi [Çevrimiçi sürüm]. Ahmet Keleşoğlu Eğitim Fakültesi Dergisi, 28, 253-272.

Artan, İ. (2001). Engelli çocukların eğitiminde etkili bir teknik: Müzik. Gazi Eğitim Fakültesi Dergisi, 21(2), 43-55.

Babaoğlan, E., \& Yılmaz, Ş. (2010). Sınıf öğretmenlerinin kaynaştırma eğitimindeki yeterlikleri. Kastamonu Eğitim Dergisi, May1s, 345-354.

Başaran, I. (2001). Özel eğitim kurumlarında çalışan öğretmenlerin çalışma koşulları. Ege Eğitim Dergisi, 1(1), 41-53.

Battal, İ. (2007). Sınıf öğretmenlerinin ve branş öğretmenlerinin kaynaştırma eğitimine ilişkin yeterliliklerinin değerlendirilmesi (Yayınlanmamış Yüksek Lisans Tezi). Afyonkarahisar Kocatepe Üniversitesi, Sosyal Bilimler Enstitüsü, Afyon.

Bryant, P., Smith, D. D., \& Bryant, R. (2008). Teaching students with special needs in inclusive classrooms. Isbn-10:0-205-43092-9- Isbn-13:978-0-205-43092-5, Chapter 9, Facilitating Social Skills Promoting Positive Behavior and Facilitating Social Skills.

Cemaloğlu, N., \& Şahin-Erdemoğlu, D. (2007). Öğretmenlerin mesleki tükenmişlik düzeylerinin farklı değişkenlere göre incelenmesi. Kastamonu Eğitim Dergisi, 15(2), 465-484.

Çepni, S., Cerrah, L., \& Bacanak, A. (2002). “Sinıf öğretmenliği yapan fen öğretmenlerinin branş öğretmenliğine dönüs nedenleri ve döndüklerinde karşılaştıkları sorunlar" V.Ulusal Fen Bilimleri Ve Eğitim Kongresi.

Çetin, F., \& Çetin, Ş. (2000). İlköğretim okullarına sınıf öğretmeni olarak atanan branş öğretmenlerinin meslekle ilgili sorunları, Milli Ë̆itim Dergisi, 145.

Emmer, E. T., \& Stough, L. M. (2001). Classroom management: a critical part of educational psychology, with implications for teacher education. Educational Psychologist, 36(2), 103-112.

Erim, G., \& Caferoğlu, M. (2012). Görsel sanatlar eğitimi dersinin zihinsel engelli çocuklara katkısının özel eğitim öğretmenlerinin görüşleriyle belirlenmesi.Uludağ Üniversitesi, Eğitim Fakültesi Dergisi, 25(2), 321-342. 
Erişen, \& Çelikgöz (2003). Öğretmen adaylarının genel öğretmenlik davranışları açısından kendilerine yönelik yeterlilik algıları. Türk Ĕ̈itim Bilimleri Dergisi, 1(4), 427-439.

Gök, G., \& Erbaş, D. (2011). Okul öncesi eğitimi öğretmenlerinin kaynaştırma eğitimine ilişkin görüşleri ve önerileri. International Journal of Early Childhood Special Education, 3(1), 66-87.

Gökay, M., \& Özalp, K. (2000). Sanat eğitimi ve sanatta terapi. Sanat Psikoterapileri Derneği.

Gökyer, N., \& Özer, F. (2014). Aday öğretmenlerinin sınıf yönetimi yeterliklerine ilişkin algıları. International Periodical for the Languages, Literature and History of Turkish or Turkic, 9(2), 691-712.

Gully, S. M., Incalcaterra, K. A., Joshi, A., \& Beaubien, J. M. (2002). A meta-analysis of team-efficacy, potency, and performance: Interdependence and level of analysis as moderators of observed relationships. Journal of Applied Psychology, 87, 819-832.

Güven, E. (2011). Müzik dersleri ve kaynaştırma uygulaması. Kastamonu Eğitim Dergisi, Cilt:19 No:,3 709-718.

Güven, E., \& Çevik, D. B. (2012). Müzik öğretmeni adaylarının kaynaştırmaya ilişkin görüşlerinin belirlenmesine yönelik bir çalışma (Balıkesir Üniversitesi Örneği). Journal of Educational and Instructional Studies in the World, 2(1), 22.

Haycock, K. (1998). Good teaching matters: How Well-Qualified Teachers Can Close the Gap. A Publication of the Education Trust, 3(2).

İlhan, L. (2008). Eğitilebilir zihinsel engelli çocuklarda beden eğitimi ve sporun sosyalleşme düzeylerine etkisi. Kastamonu Ĕgitim Dergisi, 16(1), 315-324.

Jain, P. (2013). How to be a good teacher. New Delhi: Pustak Mahal.

Karacaoğlu, C. (2008). Öğretmenlerin yeterlik algıları. Yüzünci Yıl Üniversitesi, Eğitim Fakültesi Dergisi. Haziran, V(I), 70-97.

Kayabaşı, Y. (2008). Bazı değişkenler açısından öğretmenlerin mesleki tükenmişlik düzeyleri. Gazi Üniversitesi, Sosyal Bilimler Dergisi, 20.

Kazu, Y., \& Kerimgil, S. (2008). Yeni atanan öğretmenlerin hizmet içi eğitime ilişkin görüşleri. Elazığ Örneği. Gazi Üniversitesi Endüstriyel Sanatlar Eğitim Fakültesi Dergisi, 23, 14-30.

Kılıç, I. (2009). Problems encountered by primary school teachers in the teaching of music. Inonu Unıversity Journal of the Faculty of Education, 10(1), 123-137.

Ministry of national education (MEB) (2006). Milli eğitim bakanlığı öğretmen yetiştirme ve eğitimi genel müdürlüğü, temel eğitime destek projesi "Öğretmen Eğitimi Bileşeni". Ankara.

Ministry of national education (MEB) (2008). Ögrretmen yeterlikleri. ögretmenlik mesleği ve özel alan yeterlikleri. Öğretmen Yetiştirme ve Eğitimi Genel Müdürlüğü, Ankara: Millî Eğitim Basımevi. http://otmg.meb.gov.tr/YetGenel.html

Ministry of national education (MEB) (2013).

Nizamoğlu, N. (2006). Sinı öğretmenlerinin kaynaştırma uygulamalarındaki yeterlikleri (Yüksek Lisans Tezi). Abant İzzet Baysal Üniversitesi, Eğitim Fakültesi, Eğitim Bilimleri Enstitüsü. Bolu.

Oral, B. (2000). Alan dışından mezun olup sınıf öğretmenliğine atanan öğretmenlerin sınıf öğretmenliğindeki durumlarının değerlendirilmesi, Milli Ĕ̆itim Dergisi, 148, Ekim, Kasım, Aralık.

Orel, A., Zerey, Z. and Töret, G. (2004). Sını öğretmeni adaylarının kaynaştırmaya yönelik tutumlarının ıncelenmesi. Ankara Üniversitesi Ĕgitim Bilimleri Fakültesi Özel Ĕ̈itim Dergisi, 5(1), 23-33.

Oruç, S. (2007). Özel eğitim alanında çalışan öğretmenlerin tükenmişlik düzeylerinin bazı değişkenler açısından incelenmesi (Adana İli Örneği) (Yüksek Lisans Tezi). Çukurova Üniversitesi, Sosyal bilimler Enstitüsü, Adana.

Özaydın, L. and Çolak, A. (2011). Okul öncesi öğretmenlerinin kaynaştırma eğitimine ve "okul öncesi eğitimde kaynaştırma eğitimi hizmet içi eğitim programı”na ilişskin görüşleri. Kalem Eğitim ve İnsan Bilimleri Dergisi, 1(1), 189-226.

Özer, \& Gelen, (2008). Öğretmenlik mesleği genel yeterliklerine sahip olma düzeyleri hakkında ögretmen adayları ve öğretmenlerin görüşlerinin değerlendirilmesi. Mustafa Kemal Üniversitesi Sosyal Bilimler Enstitüsü Dergisi, 5(9).

Özyürek, M. (2008). Nitelikli öğretmen yetiştirmede sorunlar ve çözümler: özel eğitim örneği. Türk Eğitim Bilimleri Dergisi, 6(2), 189-226. 
Sabanc1, A., \& Şahin, A. (2006). Farklı branşlardan atanan ilköğretim okulu sınıf öğretmenlerinin yeterlik düzeyleri. Kuram ve Uygulamada Eğitim Yönetimi, 48, 531-556.

Sadioğlu, Ö., \& Oksal, A. (2008) Sınıf öğretmenliğinden mezun olan öğretmenlerle başka alanlardan mezun olan sınıf öğretmenlerinin ilkokuma yazma öğretiminde yaşadıkları güçlüklerin karşılaştırılması. İlköğretim Online, 7(1), $71-90$

Salderay, B. (2008). Türkiye'deki zihin engelliler iş okullarında görsel sanatlar dersinin ögrencilerin beceri, davranış ve meslek edinimindeki katklsına yönelik öğretmen görüşleri (Doktora Tezi). Gazi Üniversitesi. Eğitim Bilimleri Enstitüsü, Ankara.

Sanioğlu, A., Büyükkaragöz, S., Duman, S., \& Sarı, H. (2008). İlköğretim okullarındaki özel eğitim sınıflarında görevli öğretmenlerin beden eğitimi ders programı ile ilgili görüsslerinin değerlendirilmesi (Konya ili örneği). Selçuk Üniversitesi Beden Eğitimi ve Spor Bilim Dergisi, 10(2), 40-50.

Saraç, T., \& Çolak, A. (2012). Kaynaştırma uygulamaları sürecinde ilköğretim sınıf öğretmenlerinin karşılaştıkları sorunlara ilişkin görüş ve önerileri. Mersin Üniversitesi Eğitim Fakültesi Dergisi, 8(1), 13-28.

Sarı, H., \& Bozgeyikli, H. (2003). Öğretmen adaylarının özel eğitime yönelik tutumları- nın incelenmesi: karşılaştırmalı bir araştırma. Selçuk Üniversitesi Sosyal Bilimler Enstitüsü Dergisi, 9, 183-203.

Şeker, H., Deniz, S., \& Görgen, İ. (2005). Tezsiz yüksek lisans öğretmen adaylarının öğretmenlik yeterlikleri üzerine değerlendirmeleri. Kuram Ve Uygulamada Eğitim Yönetimi, 42, 237-253.

Smith, D. D. (2011). Effective Inclusive Education: Equipping Education Professionals with Necessary Skills and Knowledge. Prospects, 41(3), 323-339.

Turkish Education Association (TED), (2009). Öğretmen yeterlikleri. 1.Basım. Ankara

Türkiye'de Kaynaştırma/ bütünleştirme yoluyla eğitimin durumu. Kaynaştırma/bütünleştirmenin etkililiğini artırmak için politika ve uygulama önerileri projesi. İstanbul. (2011).

Yıkmış, A., \& Gözün, Ö. (2004). Öğretmen adaylarının kaynaştırma konusunda bilgilendirilmelerinin kaynaştırmaya yönelik tutumlarının değişimindeki etkililiği. Ankara Üniversitesi Eğitim Bilimleri Fakültesi Özel Eğitim Dergisi, 5(2), 65-77.

Yıldırım, A., \& Şimşek, H. (2008). Sosyal bilimlerde nitel araştırma yöntemleri (Güncelleştirilmiş geliştirilmiş altıncı bask1). Ankara: Seçkin.

Zengin, R., \& Akgün, Ö. (2010). Fen ve teknoloji öğretmenlerinin yeterlilikleri. E-Journal Of New World Sciences Academy, 5(1), 248-258.

\section{Copyrights}

Copyright for this article is retained by the author(s), with first publication rights granted to the journal.

This is an open-access article distributed under the terms and conditions of the Creative Commons Attribution license which permits unrestricted use, distribution, and reproduction in any medium, provided the original work is properly cited. 